\title{
Statelessness, exodus, and health: forced internal displacement and health services
}

\author{
Apátridas, éxodo y salud: desplazamiento interno \\ forzado y servicios de salud
}

\author{
Apátridas, êxodo e saúde: deslocamento interno \\ forçado e serviços de saúde
}

Adriana del Pilar Pacheco-Coral 1

doi: 10.1590/0102-311X00027518

Migration is not only an act of moving from one place to another, but a complex process that involves phases such as preparations prior to emigration, the move, the arrival, and the return 1. Forced migration is defined as people's emigration without a clear idea of whether they want to leave or stay 2. The causes include armed conflict, ethnic or religious persecution, megaprojects development, and natural disasters ${ }^{3}$. There are basically two types of forced migrants: refugees and internally displaced persons. The difference between the two is that refugees cross international borders 4 , while the forced migration of internally displaced persons does not involve crossing borders 5 . In recent years, globalization and development processes, as well as, cross-border armed conflicts between states themselves and between states and militias 6 have led to a global increase in forced migration 7,8 .

According to the United Nations High Commissioner for Refugees (UNHCR) 9, there were 22.5 million refugees in the world in 2016. The number of internally displaced persons reached 31.1 million that same year 7. According to the Internal Displacement Monitoring Centre (IDMC), forced displacement is concentrated in Africa, the Middle East, and Latin America. The IDMC believes that forced internal displacement is "unnoticed" despite its magnitude, due to cross-border refugees' greater visibility. In addition, forced internal displacement reflects the states' weakness where the migrants are located 7. This is due to a situation of statelessness, in which migrants are deprived of their citizens' rights by force, within their own homeland 10.

The state is thus responsible for the wellbeing of internally displaced persons, as well as for restoring their rights. If the state fails to guarantee these conditions, the internally displaced will remain in their stateless condition. The IDMC also argues that if this group of migrants grows over time, it can lead to an exodus of refugees 7, due to the states' incapacity to provide solutions to this problem for their citizens.

Migration can also be considered a social phenomenon with repercussions on health. It becomes a particular challenge for public health, since migrants may have special needs. Travel medicine has already raised the hypothesis 5,11 that migrants can be carriers of infectious agents. Locals populations might be vulnerable because they have not been previously exposed to a given disease, or their immunity may be diluted with the entry of migrants. Likewise, customs, practices, and responses to the migrants' stressful situations can influence social cohesion and affect the health of local populations 12 .

Meanwhile, migrants' needs can pose a challenge to the extent that their entry reveals problems in the host areas, concerning the supply of government services such as access to healthcare 13,14 .
1 Programa de Computação Científica, Fundação Oswaldo Cruz, Rio de Janeiro, Brasil.

\section{Correspondence}

A. P. Pacheco-Coral

Programa de Computação

Científica, Fundação

Oswaldo Cruz.

Av. Brasil 4365, Rio de

Janeiro, $R J$

21040-360, Brasil.

a.pacheco-coral.11@alumni. ucl.ac.uk 
According to Lassetter \& Callister 15, migrants' health is not necessarily poor, but the migration process and various social factors can negatively affect their health, including determinants like the length of stay in host areas, exposure to diseases, lifestyle changes, cultural barriers and stigma, lack of healthy practices, and barriers to healthcare. In forced migration, such determinants are influenced by the migration pattern, the kind of armed conflict, the existing health system, the social and demographic profile, and the health needs of forced migrants.

In the case of internal forced displacement, during the preparatory phase prior to migration, the migrants may be exposed to poverty, inequalities, threats to their physical integrity, and violation of their human rights 16,17 . From the demographic point of view, forced migrants do not wish to migrate and settle elsewhere, so they cannot plan their migration or adapt easily to their new surroundings 18 . The type of armed conflict can also vary and thus influence the migration pattern. For example, an acute and flagrant armed conflict in which militias fight national armies leads to mass displacements at specific times. On the other hand, low-intensity armed conflicts can lead to continuous forced displacements of small groups over time. Such differences in the flow of migrants pose distinct challenges for health services in border areas. The services should plan how they provide care to the internally displaced, according to national government guidelines.

In forced internal displacement, the state determines how the forced migrants access health services in their own country. To achieve this ideal requires meeting at least two conditions. First, there must be consistency in the official numbers of internally displaced persons 7,8 , which can be very complex in wartime scenarios. Second, it is necessary a clear definition of the actor responsible for providing health services according to the duration of forced internal displacement. Recent displaced persons living in camps, usually receive health services through humanitarian agencies, nongovernmental organizations, and local governments 14 . Meanwhile, for those who have not arrived recently and are settled in urban areas, the local health systems should be responsible for providing the services and should guarantee that the internally displaced persons receive similar care to that of locals 6,14.

Displaced people's characteristics can vary according to how they are displaced from their homes (acute versus low-intensity armed conflict), the kind of location in their new surroundings (camps versus urban settlements), and the country's socioeconomic level (low, middle, or high-income). It is thus possible to have either very young populations or elderly ones, and a predominance of either males or females 14,19. Finally, these factors as a whole affect the kind of health needs of internally displaced persons. In general, they can have mental health problems related to the armed conflict or even the displacement itself 20 . They can have physical sequelae and disabilities resulting from the surrounding conflict 6 . In the case of women, they may have suffered sexual abuse during the armed conflict 21 . As for recent internal displacement, the main diseases are infections (mostly gastrointestinal, parasitic, including vector-borne, skin, and sexually transmitted) and those related to lacks in vaccination 14 . For internally displaced persons who are already settled, there is a predominance of chronic diseases 14 and urban problems such as violence and drug addiction.

Finally, forced internal displacement is a complex phenomenon immersed in global socioeconomic and political conditions. It affects the health of migrants and local residents and poses a persistent challenge for health systems and governments. The rising numbers of internally displaced persons in the world should motivate health providers and professionals, public health experts, researchers, and government representatives to create sustainable solutions to effectively solve the health needs of these populations. 
1. Gushulak B. Health determinants in migrants: the impact of population mobility. In: Krieken PJV, editor. Health, migration and return: a handbook for a multidisciplinary approach. The Hague: T. M. C. Asser Press/Kluwer Law International; 2001. p. 263-5.

2. Petersen W. A general typology of migration. Am Sociol Rev 1958; 23:256-66.

3. Muggah R. Through the developmentalist's looking glass: conflict-induced displacement and involuntary resettlement in Colombia. J Refug Stud 2000; 13:133-64.

4. United Nations High Commissioner for Refugees. The state of the world's refugees. https://books.google.com.br/books? $\mathrm{id}=9 \mathrm{nAVnQEACAAJ}$ (accessed on 01/Feb/ 2018).

5. MacPherson DW, Gushulak BD, Macdonald L. Health and foreign policy: influences of migration and population mobility. Bull World Health Organ 2007; 85:200-6.

6. Kett M. Displaced populations and long term humanitarian assistance. BMJ 2005; 331: 98-100.

7. Internal Displacement Monitoring Centre; Norwegian Refugee Center. Global report on internal displacement. http://www. internal-displacement.org/global-report/ grid2017/\#download (accessed on 01/Feb/ 2018).

8. Pacheco-Coral A. The role of migration processes in dengue fever occurrence in Colombia: a mixed study approach [Doctoral Dissertation]. London: University College London; 2016.

9. United Nations High Commissioner for Refugees. Figures at a glance. http://www.unhcr. org/figures-at-a-glance.html (accessed on 02/ Jan/2018).

10. Arendt $\mathrm{H}$. The origins of totalitarianism. New York: Penguin Books Limited; 1976.

11. Gushulak BD, MacPherson DW, MacPherson DA. Migration medicine and health: principles and practice. Hamilton: BC Decker Incorporated; 2006
12. Dunn JR, Dyck I. Social determinants of health in Canada's immigrant population: results from the National Population Health Survey. Soc Sci Med 2000; 51:1573-93.

13. Leaning J, Spiegel P, Crisp J. Public health equity in refugee situations. Confl Health 2011; $5: 6$

14. Spiegel PB, Checchi F, Colombo S, Paik E. Health-care needs of people affected by conflict: future trends and changing frameworks. Lancet 2010; 375:341-5.

15. Lassetter JH, Callister LC. The impact of migration on the health of voluntary migrants in western societies. A review of the literature. J Transcult Nurs 2009; 20:93-104.

16. Thomas SL, Thomas SD. Displacement and health. Br Med Bull 2004; 69:115-27.

17. Consultoría para el Desplazamiento Forzado y los Derechos Humanos. Un país que huye. Desplazamiento y violencia en una nación fragmentada. Bogotá: Editora Guadalupe; 1999.

18. Ruiz Ruiz NY. Las particularidades del proceso urbanizador en Colombia. Bitácora Urbano Territorial 2008; 1:91-104.

19. Ruíz-Ruíz N. El desplazamiento forzado en el interior de Colombia: caracterización sociodemográfica y pautas de distribución territorial 2000-2004 [Doctoral Dissertation]. Barcelona: Universidad Autónoma de Barcelona; 2007.

20. Khan S. Provision of health assistance to internally displaced persons of South Waziristan agency in camps. International Journal of Public Administration and Management Research 2014; 2:84-97.

21. Centro Nacional de Memoria Histórica. La guerra inscrita en el cuerpo. Informe nacional de violencia sexual en el conflicto armado. Bogotá: Panamericana Formas e Impresos S.A.; 2017. 